\title{
RESENHAS
}

\section{Metodologías artísticas de investigación en educación}

\section{por Sandra Rosado Fernandes}

Acabado de publicar, o livro, da autoria de Joaquín Roldán e Ricardo Marín Viadel, pretende ser uma introdução às metodologias artísticas de investigação. Roldán é escultor, fotógrafo e professor de educação artística na Universidade de Granada, e o seu trabalho tem incidido no uso da fotografia na investigação em educação. Ricardo Marín Viadel é professor de educação artística na Faculdade de Belas Artes e na Faculdade de Educação da Universidade de Granada, e tem realizado exposições e editado livros onde é visível o seu trabalho com as metodologias artísticas de investigação em educação e nas artes visuais.

As metodologias artísticas de investigação surgiram recentemente no âmbito das investigações em ciências sociais e humanas, com uma abordagem próxima da criação artística, nas suas diferentes linguagens.

Segundo os autores, este livro tem como objetivo motivar a utilização destas metodologias em novas investigações e levar as universidades a apoiarem estas investigações, com vista à sua difusão e ao seu desenvolvimento. Por este facto, apresenta-se também como um "catálogo" de experiências neste campo, onde se esboçam e sugerem as possibilidades destas metodologias de investigação na educação.

O livro centra-se nas metodologias de investigação educativa baseadas nas artes visuais e, sobretudo, na fotografia digital, daí o seu caráter eminentemente visual. As imagens surgem abundantemente ao longo do texto como argumento das suas possibilidades de utilização na investigação. Esta é, como referimos, a área de trabalho dos autores, que apresentam aqui algumas das investigações realizadas com os seus alunos dos cursos de Belas Artes e Ciências da Educação.

O livro desenvolve-se em duas partes: na primeira, os autores apresentam fundamentação teórica que sustenta as metodologias artísticas de investigação; na segunda parte são apresentadas algumas investigações baseadas nestas metodologias.

A primeira parte, divide-se em cinco capítulos. No primeiro capítulo, Ricardo Marín Viadel, procura comparar as metodologias artísticas de investigação com outras metodologias normalmente usadas na investigação em ciências sociais e humanas.

Integradas nas abordagens qualitativas, estas metodologias possibilitam, segundo o autor, novas formas de conhecimento e uma dessas formas é a arte (p.24). Apesar da investigação em educação artística recorrer às mais diferentes

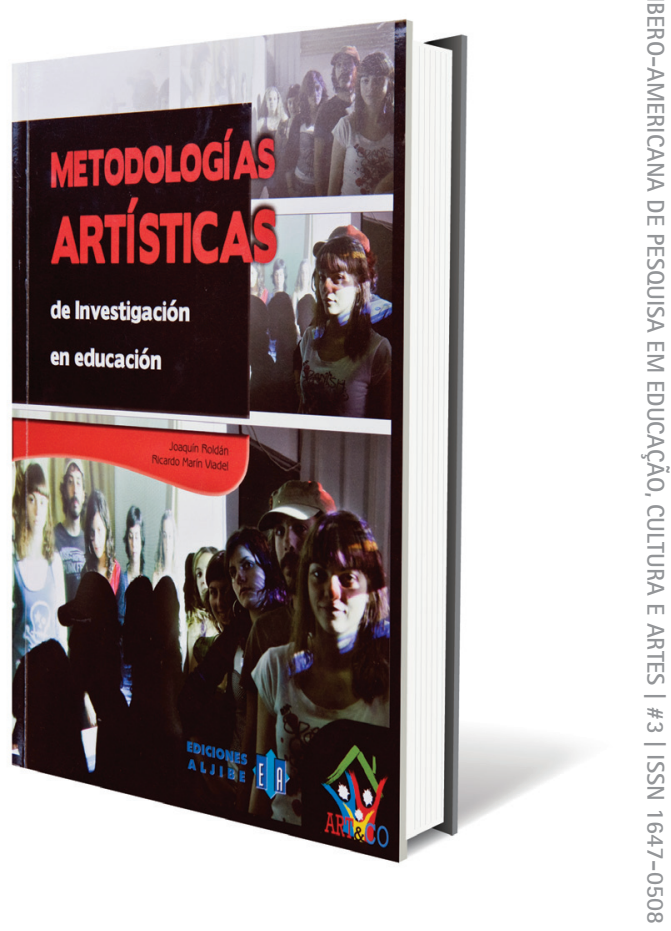

Título: Metodologías artísticas de investigación en educación

Autores: Joaquín Roldán e Ricardo Viadel (2012)

Editora: Ediciones Aljibe 
metodologias, desde abordagens qualitativas a modelos mais positivistas, foi no seio destas investigações que surgiram as metodologias artísticas de investigação, sendo a sua principal característica a enfâse dada à qualidade estética na apresentação dos processos e resultados das investigações (p.24), recorrendo a diferentes linguagens (por ex. teatral, musical, fotográfica, cinematográfica, etc.), não necessariamente à linguagem verbal.

Neste capítulo, o autor confronta-nos ainda com uma pluralidade de terminologias que correspondem a diferentes nuances na apropriação que se foi operando destas metodologias (Art For Scolarship's Sake - Arte produzida a partir da atividade do artista/investigador -, $A / R /$ Tography - procura a fusão das atividades docentes, artísticas e investigativas -, Arts-based Educational Research - investigação educativa baseada nas artes -, Arts-based Visual Research - investigação visual baseada nas artes -, Arts-based Research - investigação baseada nas artes - e Arts-informed Research - investigação informada nas artes).

A investigação educativa baseada nas artes visuais, vai buscar a sua inspiração às linguagens visuais para responder aos problemas educativos, e recorre às imagens para apresentar os dados, as ideias, os argumentos e as conclusões das investigações neste campo (p.36).

No segundo capítulo, Joaquín Roldán, analisa as diferentes utilizações da fotografia na investigação educativa.

O autor considera que o uso da imagem fotográfica pode reduzir-se a duas situações: uma, utiliza a fotografia como um instrumento para documentar algo - a imagem é um dado; outra, considera a fotografia um modelo de pensamento visual - a imagem é uma ideia. Na primeira, o uso é extrínseco, na segunda, intrínseco (p.42).

Uma investigação educativa baseada na fotografia utiliza as imagens e os processos fotográficos no seu desenvolvimento. Neste capítulo, o autor tenta explorar as possibilidades oferecidas pela fotografia na investigação educativa, quer através do seu uso extrínseco, quer intrínseco.

Nos capítulos 3, 4 e 5, os autores propõem vários modelos de organização de imagens visuais que procuram criar estruturas narrativas e argumentativas em investigação. Alguns baseiam-se no trabalho tradicionalmente desenvolvido pelos fotógrafos profissionais, outros são bastante inovadores, e por isso não estão isentos de polémica quando se argumenta que estes podem ser considerados como instrumentos de investigação no âmbito das metodologias artísticas de investigação.

Ao longo dos capítulos são apresentadas várias propostas metodológicas que utilizam a fotografia, a montagem cinematográfica e a escultura nas investigações educativas. Os modelos de organização de imagens integram o "foto-discurso", o "comentário visual", o foto-ensaio", ou a "série visual", sendo que cada modelo serve diferentes objetivos de investigação. 
Na segunda parte apresentam-se quatro investigações desenvolvidas em diferentes níveis educativos, desde a educação pré-escolar ao ensino superior.

O capítulo 6 descreve um "Foto-ensaio" (conjunto de imagens interrelacionadas que concorrem para a clarificação de uma ideia ou raciocínio), realizado por uma educadora com crianças de 3 e 4 anos, numa sala de pré-escolar. A intenção foi suscitar o debate sobre as funções, possibilidades e limites das imagens e das palavras nas investigações educativas e artísticas.

No capítulo 7 apresenta-se um projeto de inovação docente baseado num "Foto-diálogo" (diálogo através de fotografias). A utilização deste instrumento de ensino, que recorre às novas tecnologias, tem como finalidade a aprendizagem de conceitos fotográficos, e não das técnicas, ou seja, pretendeu-se desenvolver o pensamento visual fotográfico e, simultaneamente, ensinar fotografia através de fotografias (p.164).

Nos capítulos 8 e 9, os autores abordam o tema da formação dos espectadores de obras de arte, através da "Foto-história" e da "Foto-crónica", recorrendo às obras de Honoré Daumier e às fotografias de Thomas Struth, respetivamente, assim como aos conceitos e estruturas narrativas de Henri Cartier-Bresson e Bruno Munari.

No último capítulo, de conclusões, os autores sugerem que se adaptem às investigações educativas que utilizam as metodologias artísticas de investigação baseadas nas artes visuais os critérios de qualidade estabelecidos para as metodologias tradicionais e/ou se recorra aos critérios vigentes para os trabalhos artísticos profissionais.

Assim, uma investigação educativa baseada nas artes visuais deve reunir quatro requisitos: i) contribuir de forma inovadora para o conhecimento social; ii) investigar um problema educativo; iii) o seu principal contributo deve consistir em novas imagens e ideias visuais; iv) estas imagens devem ter uma qualidade artística equivalente à que se exige das imagens produzidas pelos artistas profissionais (p.236).

Em conclusão, penso que este livro representa um contributo para todos aqueles que desenvolvem as suas investigações no campo educativo e, especialmente, para os que pretendem recorrer às artes visuais como metodologia de investigação, pois, tal como referem os autores, as imagens visuais e a linguagem verbal não são redutíveis uma à outra - trata-se de domínios de representação diferentes mas complementares.

Sandra Rosado Fernandes

Docente da Escola Superior de Educação de Lisboa

\section{Referência bibliográfica:}

Roldán, Joaquín; Marín Viadel, Ricardo (2012). Metodologías artísticas de investigación en educación. (276 p.) Málaga: Ediciones Aljibe. ISBN 978-84-9700-717-7 